TITLE:

\title{
Electrochemical Synthesis of Graphite-Tetrafluoroaluminate Intercalation Compounds
}

$\operatorname{AUTHOR}(S)$ :

Matsumoto, Kazuhiko; Takagi, Kosuke; Hagiwara, Rika

\section{CITATION:}

Matsumoto, Kazuhiko ...[et al]. Electrochemical Synthesis of Graphite-

Tetrafluoroaluminate Intercalation Compounds. Journal of The Electrochemical Society 2012, 159(11): H876-H880

ISSUE DATE:

2012-01

URL:

http://hdl.handle.net/2433/259812

\section{RIGHT:}

(c) The Electrochemical Society, Inc. 2012. All rights reserved. Except as provided under U.S. copyright law, this work may not be reproduced, resold, distributed, or modified without the express permission of The Electrochemical Society (ECS). The archival version of this work was published in 'J. Electrochem. Soc. 159(11), H876-H880'; This is not the published version. Please cite only the published version.; この論文は出版社版でありません。引用の際には出版社版 をご確認ご利用ください。 
Electrochemical synthesis of graphite-tetrafluoroaluminate intercalation compounds

Kazuhiko Matsumoto, ${ }^{*}$ Kosuke Takagi, Rika Hagiwara ${ }^{\mathrm{z}, *}$

Graduate School of Energy Science, Kyoto University, Yoshida Sakyo-ku, Kyoto 606-8501, Japan

* Electrochemical Society Active Member.

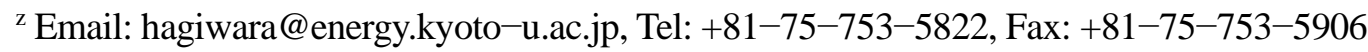




\section{Abstract}

Graphite tetrafluoroaluminate intercalation compounds ( $\left.\mathrm{AlF}_{4}-\mathrm{GICs}\right)$ have been prepared by electrochemical oxidation of a natural graphite electrode in a $1.0 \mathrm{M}$ nitromethane solution of tetraethylammmonium tetrafluoroaluminate $\left([\mathrm{TEA}]\left[\mathrm{AlF}_{4}\right]\right)$. Galvanostatic electrolysis suggests that the intercalation reaction occurs above $0.8 \mathrm{~V}$ vs. $\mathrm{Ag}^{+} / \mathrm{Ag}$. Powder X-ray diffraction measurements of the $\mathrm{AlF}_{4}-\mathrm{GIC}$ obtained by potentiostatic electrolysis reveal that the most $\mathrm{AlF}_{4}$-rich phase is the stage-3 GIC with a gallery height of $0.79 \mathrm{~nm}$. This gallery height agrees with the theoretical value calculated from the size of $\mathrm{AlF}_{4}^{-}$that locates its two-fold axis perpendicular to the graphite layers. Co-intercalation of the solvent is suggested by the composition of the stage- $3 \mathrm{GIC}\left(\mathrm{C}_{55} \mathrm{AlF}_{4}\right)$ and is confirmed by release of the solvent above $350 \mathrm{~K}$ during thermogravimetric analysis. Although the $\mathrm{AlF}_{4}$-GIC shows the higher air stability than those of the GICs with typical inorganic complex anions, it slowly decomposes into GICs at higher stages after exposure to the air over $1000 \mathrm{~h}$. Increase of gallery height was observed during this period, which possibly results from reorientation of $\mathrm{AlF}_{4}^{-}$between the layers. The thermodynamic stability of $\mathrm{AlF}_{4}$-GIC is evaluated based on a Born-Harber cycle. 


\section{Introduction}

Graphite intercalation compounds (GICs) were extensively studied by many chemists and physicists during the latter half of the last century due to their unique structural and electronic properties. ${ }^{1-3}$ Since many compounds were found to exhibit electronic conductivities higher than that of the original graphite, they were called synthetic metals and their applications were envisaged as conductive materials lighter than metals. They are classified into two categories, donor- and accepter-types. The donor-type GICs are formed by reduction of the host graphite layers along with the intercalation of the guest species represented by alkali metal cations. The most successful application of GICs to date is actually not as electronic conductors but as the negative electrode of lithium ion batteries taking advantage of the reversible topotactic intercalation and deintercalation of lithium ion into and out of the host graphite. ${ }^{4}$ The acceptor-type GICs are formed by oxidation of the graphite layers and intercalation of anionic guest species. The practical applicationsof the acceptor-type GICs has not been as successful as that of the donor-type GIC except for sulfate GIC as precursors for the preparation of exfoliated graphite..$^{5,6}$

Various fluoroanions are known to be intercalated into graphite, such as $\mathrm{BF}_{4}^{-7},{ }^{-9} \mathrm{PF}_{6}^{-10,}{ }^{11}$ $\mathrm{AsF}_{6}{ }^{-12}$ and $\mathrm{SbF}_{6}{ }^{-13}$ Even bulky anions with perfluoroorganic-group such as $\mathrm{PF}_{3}\left(\mathrm{C}_{2} \mathrm{~F}_{5}\right)_{3}$ and $\mathrm{R}_{\mathrm{f}} \mathrm{SO}_{3}\left(\mathrm{R}_{\mathrm{f}}=\right.$ long perfluoroorganic group $)$ can be intercalated into graphite layers by significantly expanding the layer spacing. ${ }^{4,14,15}$ The selection of the guest anion is an important factor to determine properties of acceptor-type GICs. Among a series of fluoroanions, the tetrafluoroaluminate anion $\left(\mathrm{AlF}_{4}^{-}\right)$is one of the missing examples as a guest anion in GICs. The 
$\mathrm{AlF}_{4}^{-}$anion tends to form a polymeric structure and only a few salts with bulky organic cations contain the isolated tetrahedral $\mathrm{AlF}_{4}^{-}$in both the solid and liquid states. ${ }^{16-18}$ There are reports on the chemical reaction of $\mathrm{AlF}_{3}$ and graphite in the presence of elemental fluorine. ${ }^{19,20}$ The product obtained by this reaction was not characterized as a GIC containing $\mathrm{AlF}_{4}^{-}$, but was expressed as a GIC with a composition of $\mathrm{C}_{x} \mathrm{~F}\left(\mathrm{AlF}_{3}\right)_{y}$. This is in contrast to the well-known $\mathrm{AlCl}_{4}$ - and $\mathrm{AlBr}_{4}-\mathrm{GICs}{ }^{1}$

This study reports the first synthesis of $\mathrm{AlF}_{4}-\mathrm{GIC}$ by anodic oxidation of a graphite electrode in an organic medium containing $\mathrm{AlF}_{4}^{-}$. The unique compound was characterized by means of $\mathrm{X}^{-}$ ray diffraction and thermogravimetric analyses. The thermodynamic stability of $\mathrm{AlF}_{4}-\mathrm{GIC}$ will be discussed using a Born-Haber cycle.

\section{Experimental}

General and Reagents. Air sensitive materials were handled in a glove box under a dried and deoxygenated argon atmosphere. Silver tetrafluoroborate (Wako Pure Chemical Industries, Ltd., Purity $97 \%$ ), tetraethylammonium tetrafluoroborate ([TEA][BF $]$, Tokyo Chemical Industry Co., Ltd., purity > $98 \%$ ), [TEA]Cl (Tokyo Chemical Industry Co., Ltd., purity > $98.0 \%$ ), anhydrous $\mathrm{AlCl}_{3}$ (Wako Pure Chemical Industries, Ltd., purity $99.9 \%$ ), acetonitrile (Wako Pure Chemical Industries, Ltd., water content $\leq 50 \mathrm{ppm}$ ), and nitromethane (Sigma-Aldrich Co., purity $\geq 98.5 \%$, water content $\leq 100 \mathrm{ppm}$ ), and SP-1 graphite powder (Union Carbide Corp., average particle diameter $100 \mu \mathrm{m}$, purity $99.4 \%$ ) were used as supplied. The starting material, [TEA][ $\left.\mathrm{AlCl}_{4}\right]$, was prepared by the equimolar reaction of $\mathrm{AlCl}_{3}$ and [TEA]Cl in acetonitrile, followed by removal of 
the solvent under vacuum at 343 K. Anhydrous HF (Stella Chemifa Corp., purity $99.9 \%$ ), was dried over $\mathrm{K}_{2} \mathrm{NiF}_{6}(\mathrm{Ozark}-\mathrm{Mahoning}$ Elf Atochem North America Inc.) prior to use (for treatment of anhydrous HF, see previous works ${ }^{21,22}$ ).

Synthesis of [TEA][AlF 4 ]. A large excess of anhydrous HF (aHF) was distilled onto $3.473 \mathrm{~g}$ of [TEA][AlCl 4$]\left(1.161 \times 10^{-2} \mathrm{~mol}\right)$ in a tetrafluoroethylene-perfluoroalkylvinylether copolymer (PFA) reactor at $77 \mathrm{~K}$ and the mixture was slowly warmed up to room temperature. The pressure inside the reactor rose due to evolution of $\mathrm{HCl}$ and the pressure of the reactor was carefully controlled by releasing the gas to the chemical trap. The temperature of the reactor was also controlled by an appropriate coolant. The byproduct $\mathrm{HCl}$ was pumped off together with excess $\mathrm{HF}$ at room temperature once the reaction ceased and a homogeneous liquid was obtained. Addition and elimination of aHF were repeated again to complete the reaction. The final product, [TEA][AlF $]$, was obtained by evacuating the sample at $383 \mathrm{~K}$ for one day $\left(2.707 \mathrm{~g}, 1.161 \times 10^{-2}\right.$ mol). Anal. Calcd. for $\mathrm{C}_{8} \mathrm{H}_{20} \mathrm{NF}_{4}: \mathrm{C}, 41.20 ; \mathrm{H}, 8.64 ; \mathrm{N}, 6.01 ; \mathrm{F}, 32.58$. Found: $\mathrm{C}, 40.80 ; \mathrm{H}$, 8.68; N, 5.96; F, 32.86. IR (frequency/cm $\left.{ }^{-1}\right): 785\left(\mathrm{AlF}_{4}^{-}\right)$.

Electrode preparation and electrochemical measurement. Graphite powder and KF polymer (Kureha Corp) were mixed in the $85: 15$ mass ratio of graphite and poly(vinylidene fluoride) (PVdF). This slurry was painted on a nickel mesh current collector (Nilaco Corp., 50 mesh) which was spot-welded to a nickel wire and electrochemically polished in sulfuric acid prior to use. The obtained electrode was dried under vacuum at $393 \mathrm{~K}$ for one day. The reference electrode was made by immersing a silver wire in a $0.01 \mathrm{M} \mathrm{AgBF} 4+0.1 \mathrm{M}[\mathrm{TEA}]\left[\mathrm{BF}_{4}\right]$ / $\mathrm{CH}_{3} \mathrm{NO}_{2}$ solution in a glass sample holder which was separated from the electrolytic solution by 
porous Vycor glass (BAS Inc.). A counter electrode was prepared in the same manner as the working electrode and separated from the electrolytic solution by thin porous Vycor glass to minimize the effects of the product from the counter electrode. Electrochemical measurements were performed at $298 \mathrm{~K}$ with the aid of an electrochemical measurement system HZ-3000 (Hokuto Denko). The electrolytic solution was prepared by dissolving [TEA][AlF 4 into nitromethane (1 M).

Analysis. X-ray diffraction patterns were recorded by a powder X-ray diffractometer, Ultima IV (Rigaku Corp., $\mathrm{CuK} \alpha$ radiation, $40 \mathrm{kV}-40 \mathrm{~mA}$ ). Air sensitive samples were placed in an air-tight cell with beryllium windows (Rigaku Corp.) under a dry argon atmosphere. Infrared spectra of [TEA $]\left[\mathrm{AlF}_{4}\right]$ was obtained by using a FTS-155 spectrometer (Bio-Rad Laboratories Inc.). The sample compartment was filled with a dry argon gas during measurements. The samples were sandwiched between a pair of silver chloride windows in an air-tight cell under a dry argon atmosphere. Thermal decomposition behavior was analyzed by a differential thermogravimetric analyzer, DTG-60H (Shimadzu Corp.). Nickel cells were washed with acetone just before measurements and dried by heating. The measurement was performed at a scan rate of $5 \mathrm{~K} \mathrm{~min}^{-1}$ under the flow of dry argon gas $\left(50 \mathrm{~mL} \mathrm{~min}^{-1}\right)$. The sample was heated from room temperature to $573 \mathrm{~K}$ and held there for 30 minutes. Elemental analysis was performed at the elemental analysis center in Institute for Chemical Research, Kyoto University.

\section{Results and Discussion}

Cyclic voltammetry and galvanostatic electrolysis. Figure 1 (a) shows the cyclic voltammogram 
of a nickel plate in $1 \mathrm{M}$ [TEA] $\left[\mathrm{AlF}_{4}\right] / \mathrm{CH}_{3} \mathrm{NO}_{2}$. During the anodic sweep, no obvious anodic current is observed due to passivation of the surface of the nickel electrode. A cathodic current ascribed to decomposition of the electrolytic solution is observed at $-2.2 \mathrm{~V} \mathrm{vs.} \mathrm{Ag}^{+} / \mathrm{Ag}$ during the cathodic sweep. A cyclic voltammogram of a graphite electrode in $1 \mathrm{M}$ [TEA][AlF 4$] / \mathrm{CH}_{3} \mathrm{NO}_{2}$ is shown in Figure 1 (b). Anodic current is observed at $0.8 \mathrm{~V}$ vs. $\mathrm{Ag}^{+} / \mathrm{Ag}$ during the anodic sweep, suggesting intercalation of $\mathrm{AlF}_{4}^{-}$into graphite layers (eq. (1)). On reversing the sweep direction, a cathodic current corresponding to de-intercalation of $\mathrm{AlF}_{4}^{-}$is observed.

$$
x \mathrm{C}+\mathrm{AlF}_{4}^{-} \rightleftarrows \mathrm{C}_{x} \mathrm{AlF}_{4}+\mathrm{e}
$$

The value of $Q_{\mathrm{d}} / Q_{\mathrm{a}}$ is 0.78 , where $Q_{\mathrm{c}}$ and $Q_{\mathrm{a}}$ denote the cathodic and anodic charges in the cyclic voltammogram, respectively. This value indicates that a part of intercalated $\mathrm{AlF}_{4}^{-}$remains in graphite layers after the cathodic sweep. The low $Q_{\mathrm{d}} / Q_{\mathrm{a}}$ value is typical for the intercalation of inorganic complex anions such as $\mathrm{BF}_{4}^{-}$and $\mathrm{PF}_{6}{ }^{-}$into graphite in nonaqueous electrolytes. ${ }^{7,8,11,23}$

Figure 2 shows a galvanostatic charge profile of a graphite electrode in $1 \mathrm{M}$ [TEA][AlF 4$]$ / $\mathrm{CH}_{3} \mathrm{NO}_{2}$ at a current density of $10 \mathrm{~mA} \mathrm{~g}^{-1}$. The profile shows a gentle gradient in the range of 0.8-1.2 V vs. $\mathrm{Ag}^{+} / \mathrm{Ag}$, which indicates phase transitions from the GIC with a higher stage number to that with the lower stage number. Above $1.2 \mathrm{~V}$ vs. $\mathrm{Ag}^{+} / \mathrm{Ag}$, the potential increased steeply, suggesting oxidation of the lowest-stage GIC or anodic decomposition of the electrolyte on the GIC.

Potentiostatic electrolysis. Figure 3 shows a chronoamperogram of a graphite electrode in $1 \mathrm{M}$ [TEA] $\left[\mathrm{AlF}_{4}\right] / \mathrm{CH}_{3} \mathrm{NO}_{2}$ during potentiostatic electrolysis at $1.1 \mathrm{~V}$ vs. $\mathrm{Ag}^{+} / \mathrm{Ag}$. The current density 
decreased with an increase in electrolysis time and the total charge reached $168 \mathrm{C} \mathrm{g}^{-1}$ at $1800 \mathrm{~s}$. This charge density corresponds to the composition of $\mathrm{C}_{48} \mathrm{AlF}_{4}$.

An XRD profile of the electrode after the potentiostatic electrolysis (without washing) is shown in Figure 4. Structural parameters obtained from this XRD pattern are listed in Table 1. This GIC can be indexed as a stage-3 compound ( $n=3)$ according to the following eq. (2):

$$
(n+1) d_{00 n+1}=(n+2) d_{00 n+2}\left(=I_{\mathrm{c}}\right)
$$

Where $n$ and $I_{\mathrm{c}}$ denote the stage number and the unit cell repeat length (identity period) along the stacking direction, respectively.

The resulting gallery height $\left(d_{\mathrm{i}}\right)$ is in the range of $0.79-0.80 \mathrm{~nm}$; the value calculated from the (001) diffraction peak contains a large experimental error. The $d_{\mathrm{i}}$ value obtained from the most intense (004) diffraction peak is 0.795 and agrees with the calculated value of $0.791 \mathrm{~nm}$ based on the model where $\mathrm{AlF}_{4}^{-}$locates the two-fold axis perpendicular to the graphite layers as shown in Figure 5 (a) (see crystallographic data of $\left[\right.$ collidine $\left.\mathrm{H}^{+}\right]\left[\mathrm{AlF}_{4}{ }^{-}\right]$which gives the average $\mathrm{Al}-\mathrm{F}$ bond of $0.165 \mathrm{~nm}$ for the tetrahedral $\left.\mathrm{AlF}_{4}^{-}[13]\right)^{17}$. This gallery height is slightly larger than that of $\mathrm{BF}_{4}$-GIC $(0.749 \mathrm{~nm})$ with the same orientation in the graphite layers, ${ }^{9}$ as is expected from the sizes and geometry of $\mathrm{AlF}_{4}{ }^{-}$and $\mathrm{BF}_{4}{ }^{-}$. Although potentiostatic electrolysis at higher potentials was attempted, an $\mathrm{AlF}_{4}-\mathrm{GIC}$ at lower stage (stage-1 or stage-2 GICs) was not obtained.

The compositions of the obtained GICs $\left(\mathrm{C}_{48} \mathrm{AlF}_{4}\right.$ at $\left.1.1 \mathrm{~V}\right)$ suggest co-intercalation of the solvent nitromethane since the ratio of $\mathrm{AlF}_{4}^{-}$to carbon is less than that usually obtained for a 
stage- 3 compound (see the case of $\mathrm{BF}_{4}$-GIC with a composition around $\mathrm{C}_{20} \mathrm{BF}_{4}$ for a stage- 3 compound without co-intercalation). ${ }^{9}$ Similar phenomena were observed for GICs of other anions prepared in organic solutions. ${ }^{24,25}$ The thermogravimetric curve of the stage- $3 \mathrm{AlF}_{4}$-GIC is shown in Figure 6 with that of PVdF for comparison. The stage-3 $\mathrm{AlF}_{4}$-GIC steeply loses its weight from $350 \mathrm{~K}$ and reaches $94 \%$ of its original weight at $570 \mathrm{~K}$. The weight loss suggests that the amount of nitromethane $(k)$ co-intercalated with $\mathrm{AlF}_{4}^{-}$is more than 0.71 in the formula of $\mathrm{C}_{48} \mathrm{AlF}_{4}\left(\mathrm{CH}_{3} \mathrm{NO}_{2}\right)_{k}$. It should be noted that the thickness of nitromethane is small enough to be co-intercalated into the graphite layer without affecting the gallery height when its long axis is parallel to the graphite layer (cf. the crystallographically determined structure of nitromethane ${ }^{26}$ ).

Air stability and structural change. The air stability of the stage- $3 \mathrm{AlF}_{4}-\mathrm{GIC}$ was investigated by periodic XRD measurements. The sample was prepared by potentiostatic electrolysis at $1.1 \mathrm{~V}$ vs. $\mathrm{Ag}^{+} / \mathrm{Ag}$ as shown above. Figure 7 shows the change in XRD profiles of the electrochemically prepared GIC during exposure to the air at room temperature. The diffraction peaks are broadened with exposure time and formation of the higher stage GIC is suggested. It should be noted that both the (004) and (005) peaks shifted to lower angles during the first week (from $24.3^{\circ}$ to $24.0^{\circ}$ for the (004) peak and from $30.4^{\circ}$ to $29.7^{\circ}$ for the (005) peak), suggesting an increase in $d_{\mathrm{i}}$. The peak at $24.0^{\circ}$ does not shift during further exposure to the air, whereas the peak at $29.7^{\circ}$ shifted to the low angle $\left(29.4^{\circ}\right.$ after three weeks and $28.9^{\circ}$ after six weeks).

Although the diffraction patterns of the GICs after one week and three weeks are unindexable probably due to the formation of complicated solid solutions, the pattern obtained 
after six weeks in air is indexable as a stage-4 GIC with $d_{\mathrm{i}}$ of $0.845 \mathrm{~nm}\left(2 \theta=24.1^{\circ}\right.$ and $d=0.369$ $\mathrm{nm}$ for $(005)$ and $2 \theta=28.9^{\circ}$ and $d=0.309 \mathrm{~nm}$ for (006)) using eq. (2). The asymmetric shapes of these peaks suggest stage mixing or formation of solid solutions in these materials. One possible structural change during this period is reorientation of $\mathrm{AlF}_{4}^{-}$within the layer; the three-fold axis of $\mathrm{AlF}_{4}^{-}$lies perpendicular to the graphite layers with a theoretical $d_{\mathrm{i}}$ of $0.821 \mathrm{~nm}$ (Figure 5 (b), see the other case above (the two-fold axis perpendicular to the graphite layers) for calculation of $d_{\mathrm{i}}$ ). Another possibility is formation of a polymeric or oligomeric fluoroaluminate anion in the layer. ${ }^{27,28}$ Although the infinite chains consisting of $\mathrm{AlF}_{6}$ octahedra which are corner-shared to two pairs of edge-shared octahedra was reported as one of the polymeric units of $\mathrm{AlF}_{4}^{-}$, this model leads to $d_{\mathrm{i}}$ larger than $0.952 \mathrm{~nm}$ (this value is obtained in the case when the trans $\mathrm{F}-\mathrm{Al}-\mathrm{F}$ axis in a $\mathrm{AlF}_{6}$ unit with the $\mathrm{Al}-\mathrm{F}$ length of $0.176 \mathrm{~nm}$ lies perpendicular to the graphite layers) and is therefore excluded in the present case. The ladder-like $\left(\mathrm{Al}_{2} \mathrm{~F}_{8}{ }^{2-}\right)_{n}$ chain is another possible structural motif in graphite layers (Figure 5 (c)). In this case, the smallest $d_{\mathrm{i}}$ of $0.869 \mathrm{~nm}$ is based on the $\mathrm{F} \cdots \mathrm{F}$ distance $(0.268 \mathrm{~nm})$ between the two terminal fluorine atoms ( cis $^{-} \mathrm{F}-\mathrm{Al}-\mathrm{F}$ relation to each other) when the slightly zig-zag configuration of the $\mathrm{AlF}_{6}$ octahedron is ignored. This value is still too large compared to the observed $0.845 \mathrm{~nm}$ for the stage- 4 compound obtained after six-week exposure to the air. Consequently, the formation of a polymeric unit does not seem to occur in this case. The uptake of water from the air is another possible factor to contribute to the increase of $d_{\mathrm{i}}$, because $\mathrm{AlF}_{4}{ }^{-}$can transform to water-containing species, $\mathrm{AlF}_{4}\left(\mathrm{H}_{2} \mathrm{O}\right)_{l}{ }^{-27,29,30}$ However, considering the high oxidation power of fluoroanion-GICs, this is not very plausible. 
more stable in air than those of the GICs with small inorganic anions $\left(\mathrm{NO}_{3}{ }^{-}, \mathrm{SO}_{4}{ }^{2-}\right.$, and $\left.\mathrm{FHF}^{-}\right) .{ }^{31}$ They proposed that the reason for this phenomenon is the slow diffusion rate of the large guest species in GICs. Although the size of $\mathrm{AlF}_{4}^{-}$is similar to the small inorganic anions indicated, the increase in stage number for the present $\mathrm{AlF}_{4}-\mathrm{GIC}$ is slower than those with $\mathrm{NO}_{3}{ }^{-}, \mathrm{SO}_{4}{ }^{2-}$, and $\mathrm{FHF}^{-}$. The fairly stable $\mathrm{Al}-\mathrm{F}$ bond may maintain the structure of the $\mathrm{AlF}_{4}-\mathrm{GIC}$ around stage-4 even after exposure to the air over $1000 \mathrm{~h}$.

Thermodynamic stability of $\mathrm{AlF}_{4}-$ GIC.

As was pointed out by Bartlett and his co-workers, the majority of fluoroanions (from tetrahedral $\mathrm{BF}_{4}^{-}$to octahedral $\mathrm{UF}_{6}^{-}$) have approximately the same effective ionic diameter of roughly $0.50 \mathrm{~nm}$ when they are guests in graphite. ${ }^{2,32-34}$ Application of a modified Born-Haber cycle to such acceptor-type GICs of fluorometallate anions based on an ionic model shows that the thermodynamic requirement for GIC formation is predominantly governed by the formation enthalpy of fluorometallate anions from molecular fluorides (eq. 3). ${ }^{34,35}$

$$
\left.\mathrm{MF}_{n(\mathrm{~g})}+1 / 2 \mathrm{~F}_{2(\mathrm{~g})}+\mathrm{e} \rightarrow \mathrm{MF}_{n+1^{-}}{ }^{-} \mathrm{g}\right)
$$

From a series of experiments, they determined the threshold enthalpy range of this process for the intercalation into graphite to be $-440 \sim-520 \mathrm{~kJ} \mathrm{~mol}^{-1}$. Partial intercalation, namely the formation of high stage salts, occurs in this range. When the enthalpy is lower than $-520 \mathrm{~kJ} \mathrm{~mol}^{-1}$, full intercalation, i.e. formation of the 1st stage salt, occurs, whereas no intercalation proceeds 
when it is higher than $-440 \mathrm{~kJ} \mathrm{~mol}^{-1}$. The reaction step given in eq. 3 can be divided into two processes:

$$
1 / 2 \mathrm{~F}_{2(\mathrm{~g})}+\mathrm{e} \rightarrow \mathrm{F}^{-}(\mathrm{g})
$$

$$
\mathrm{MF}_{n(\mathrm{~g})}+\mathrm{F}_{(\mathrm{g})}^{-} \rightarrow \mathrm{MF}_{n+1^{-}}^{-}(\mathrm{g})
$$

The enthalpy change for the process given by eq. 4 is estimated to be $-256 \mathrm{~kJ} \mathrm{~mol}^{-1}{ }^{36}$ The enthalpy change for the process given by eq. 5 is defined as fluoride ion affinity of the Lewis acid fluorides. Thus, the threshold enthalpy change for graphite intercalation is $-180 \sim-260 \mathrm{~kJ} \mathrm{~mol}^{-1}$ in terms of fluoride ion affinity.

The fluoride ion affinity of $\mathrm{AlF}_{3}$ has been evaluated by several groups (e.g. $-548 \mathrm{~kJ}$ mol $\left.{ }^{-1}\right) .{ }^{37}$ This value indicates that the formation of the 1 st stage salt is thermochemically allowed. However, under ambient conditions, $\mathrm{AlF}_{3}$ is a stable solid and gasification enthalpy $\left(301 \mathrm{~kJ} \mathrm{~mol}^{-}\right.$ $\left.{ }^{1}\right)^{38}$ should be taken account when the reaction starts from solid $\mathrm{AlF}_{3}$ (eq. 6).

$$
\mathrm{AlF}_{3}(\mathrm{~s}) \rightarrow \mathrm{AlF}_{3}(\mathrm{~g})
$$

Therefore, the enthalpy change for the process given by eq. 7 is $-247 \mathrm{~kJ} \mathrm{~mol}^{-1}$ that falls in the range for the formation of high stage GIC. ${ }^{34,35}$ 
$\mathrm{AlF}_{3(\mathrm{~s})}+1 / 2 \mathrm{~F}_{2(\mathrm{~g})}+\mathrm{e} \rightarrow \mathrm{AlF}_{4}^{-}(\mathrm{g})$

The large gasification energy of $\mathrm{AlF}_{3}$ leads to the difficulty in synthesizing $\mathrm{AlF}_{4}$-GIC from $\mathrm{AlF}_{3}$, whereas the electrochemical synthesis using a soluble salt as an $\mathrm{AlF}_{4}^{-}$source is an effective method because it directly intercalates $\mathrm{AlF}_{4}{ }^{-}$into the graphite layers. Although a GIC at a lower stage than expected by the Born-Haber cycle may be prepared when a solvent is co-intercalated, the present study confirmed only the stage-3 GIC by the electrochemical method.

\section{Conclusion}

This study reports the first synthesis of $\mathrm{AlF}_{4}$-GIC by an electrochemical method. Cyclic voltammetry confirms intercalation of $\mathrm{AlF}_{4}{ }^{-}$into the graphite structure occurs above $0.8 \mathrm{~V}$ vs. $\mathrm{Ag}^{+} / \mathrm{Ag}$ during the anodic scan, whereas the deintercalation does not fully occur during the following cathodic scan. Galvanostatic electrolysis showed a gradual staging reaction in the range of $0.8-1.2 \mathrm{~V}$ vs. $\mathrm{Ag}^{+} / \mathrm{Ag}$. Potentiostatic electrolysis at $1.1 \mathrm{~V}$ vs. $\mathrm{Ag}^{+} / \mathrm{Ag}$ combined with XRD reveals that the GIC reached stage-3 but the lower stage GIC was not obtained. The gallery height suggests that $\mathrm{AlF}_{4}^{-}$is oriented with its two-fold axis perpendicular to the graphite layers just after the synthesis. Exposure to the air of the $\mathrm{AlF}_{4}-\mathrm{GIC}$ results in a change in the gallery height, which may be caused by the change in the orientation of $\mathrm{AlF}_{4}^{-}$(the three-fold axis perpendicular to the graphite layers). Thermodynamic evaluation using a Born-Haber cycle agrees with the stability of a $\mathrm{AlF}_{4}$-GIC forms a high-stage structure rather than a stage-one structure. 
Table 1 Structural parameters obtained from the XRD profile of the stage-3 GIC obtained by potentiostatic electrolysis of a graphite electrode at $1.1 \mathrm{~V}$ vs. $\mathrm{Ag}^{+} / \mathrm{Ag}$ in $1 \mathrm{M}$ [TEA] $\left[\mathrm{AlF}_{4}\right] /$ $\mathrm{CH}_{3} \mathrm{NO}_{2}$

\begin{tabular}{ccccc}
\hline$h k l$ & $2 \theta /$ degree & $d / \mathrm{nm}$ & $I_{\mathrm{c}} / \mathrm{nm}$ & $d_{\mathrm{i}} / \mathrm{nm}$ \\
\hline 001 & 5.95 & $1.49^{a}$ & $1.49^{a}$ & $0.82^{a}$ \\
004 & 24.3 & 0.366 & 1.465 & 0.795 \\
005 & 30.4 & 0.294 & 1.469 & 0.799 \\
- & 42.4 & 0.213 & - & - \\
- & 44.2 & 0.205 & - & - \\
008 & 49.9 & 0.183 & 1.462 & 0.792 \\
009 & 56.4 & 0.163 & 1.466 & 0.796 \\
\hline
\end{tabular}

${ }^{a}$ These values contain large experimental errors from the low $2 \theta$ angle and weak intensity. 


\section{Figure captions}

Figure 1 Cyclic voltammograms of (a) a nickel electrode and (b) a graphite electrode in $1 \mathrm{M}$ [TEA] $\left[\mathrm{AlF}_{4}\right] / \mathrm{CH}_{3} \mathrm{NO}_{2}$.

Figure 2 A galvanostatic charge profile of a graphite electrode in $1 \mathrm{M}$ [TEA] $\left[\mathrm{AlF}_{4}\right] / \mathrm{CH}_{3} \mathrm{NO}_{2}$.

Figure 3 A chronoamperogram of a graphite electrode in $1 \mathrm{M}$ [TEA] $\left[\mathrm{AlF}_{4}\right] / \mathrm{CH}_{3} \mathrm{NO}_{2}$ during potentiostatic electrolysis at $1.1 \mathrm{~V}$ vs. $\mathrm{Ag}^{+} / \mathrm{Ag}$.

Figure 4 An X-ray diffraction profile of the graphite electrode obtained by potentiostatic electrolysis at $1.1 \mathrm{~V}$ vs. $\mathrm{Ag}^{+} / \mathrm{Ag}$ in $1 \mathrm{M}[\mathrm{TEA}]\left[\mathrm{AlF}_{4}\right] / \mathrm{CH}_{3} \mathrm{NO}_{2}$. The symbol $\downarrow$ denotes the strongest diffraction peak of [TEA][AlF 4$]$.

Figure 5 (Color online) A possible alignment of $\mathrm{AlF}_{4}^{-}$in graphite layers; (a) the discrete $\mathrm{AlF}_{4}^{-}$ with the $C_{2 v}$ axis perpendicular to the graphite layers, (b) the discrete $\mathrm{AlF}_{4}^{-}$with the $C_{3 v}$ axis perpendicular to the graphite layers, and (c) the ladder-like $\left(\mathrm{Al}_{2} \mathrm{~F}_{8}{ }^{2-}\right)_{n}$ chain. The $c$-axis in the diagrams denotes the direction perpendicular to the graphite layers.

Figure 6 Thermogravimetric curves for $\mathrm{PVdF}$ and the stage-3 $\mathrm{AlF}_{4}-\mathrm{GIC}$.

Figure $7 \mathrm{X}$-ray diffraction patterns of the stage- $3 \mathrm{AlF}_{4}$-GIC obtained by potentiostatic electrolysis at $1.1 \mathrm{~V}$ vs. $\mathrm{Ag}^{+} / \mathrm{Ag}$ in $1 \mathrm{M}[\mathrm{TEA}]\left[\mathrm{AlF}_{4}\right] / \mathrm{CH}_{3} \mathrm{NO}_{2}$ during exposure to the air at room temperature. 
(a)

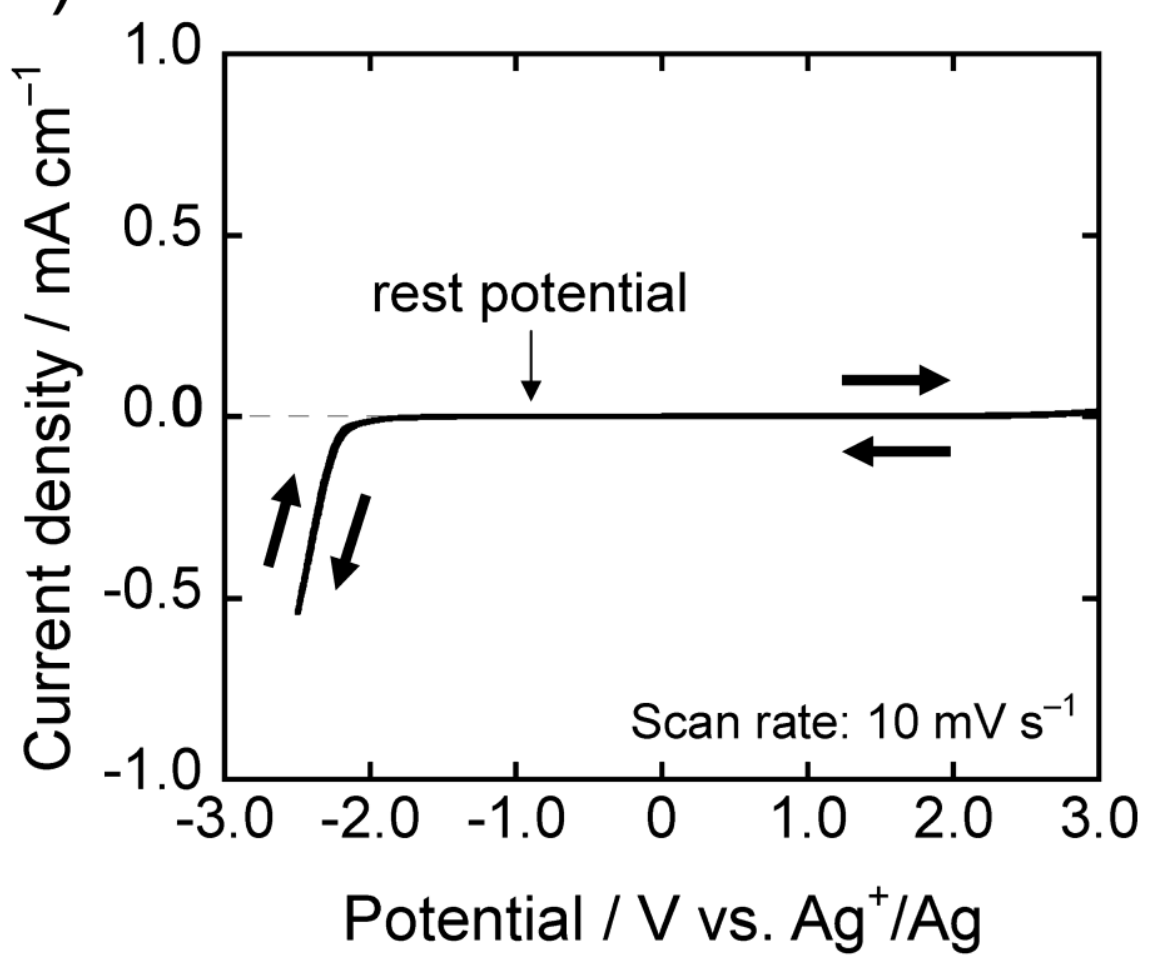

(b)

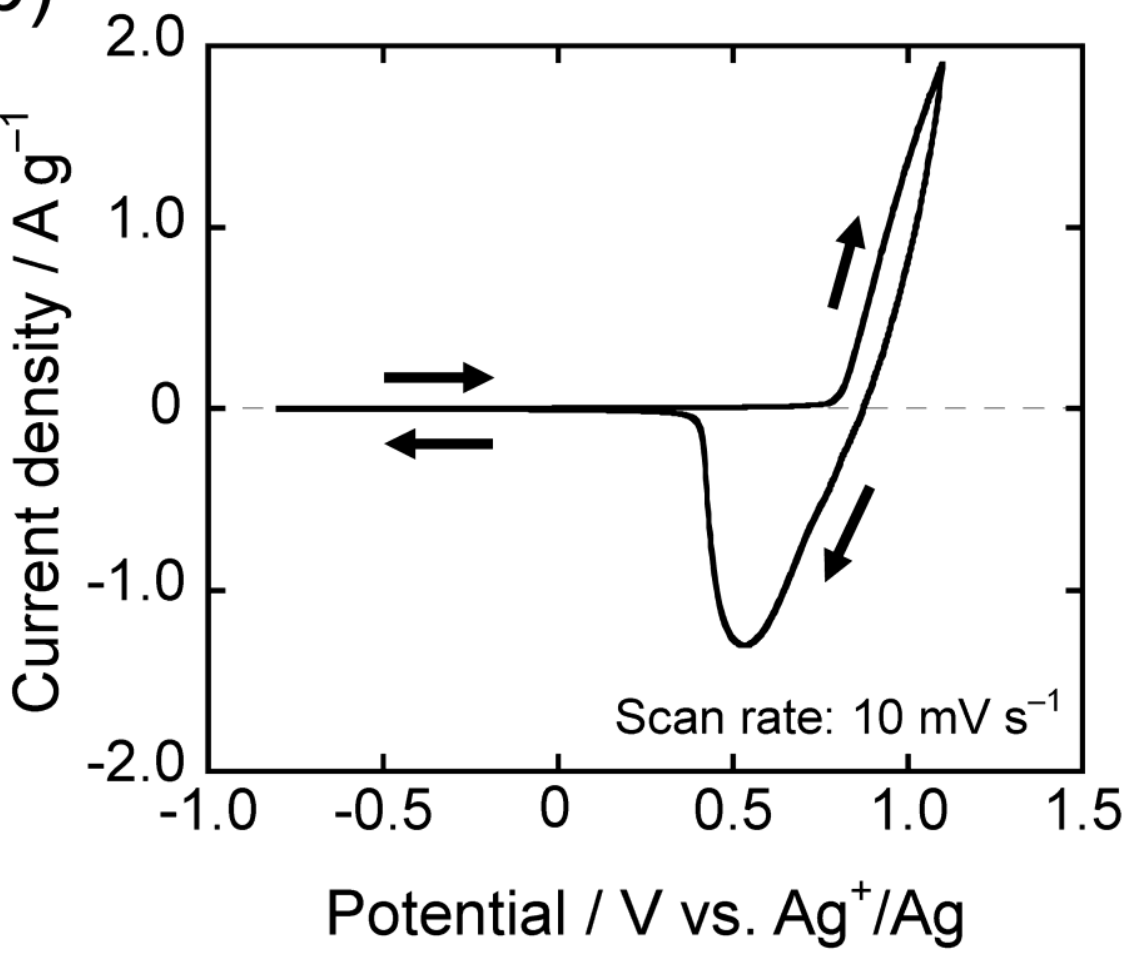

Figure 1 Cyclic voltammograms of (a) a nickel electrode and (b) a graphite electrode in $1 \mathrm{M}$ $[\mathrm{TEA}]\left[\mathrm{AlF}_{4}\right] / \mathrm{CH}_{3} \mathrm{NO}_{2}$. 


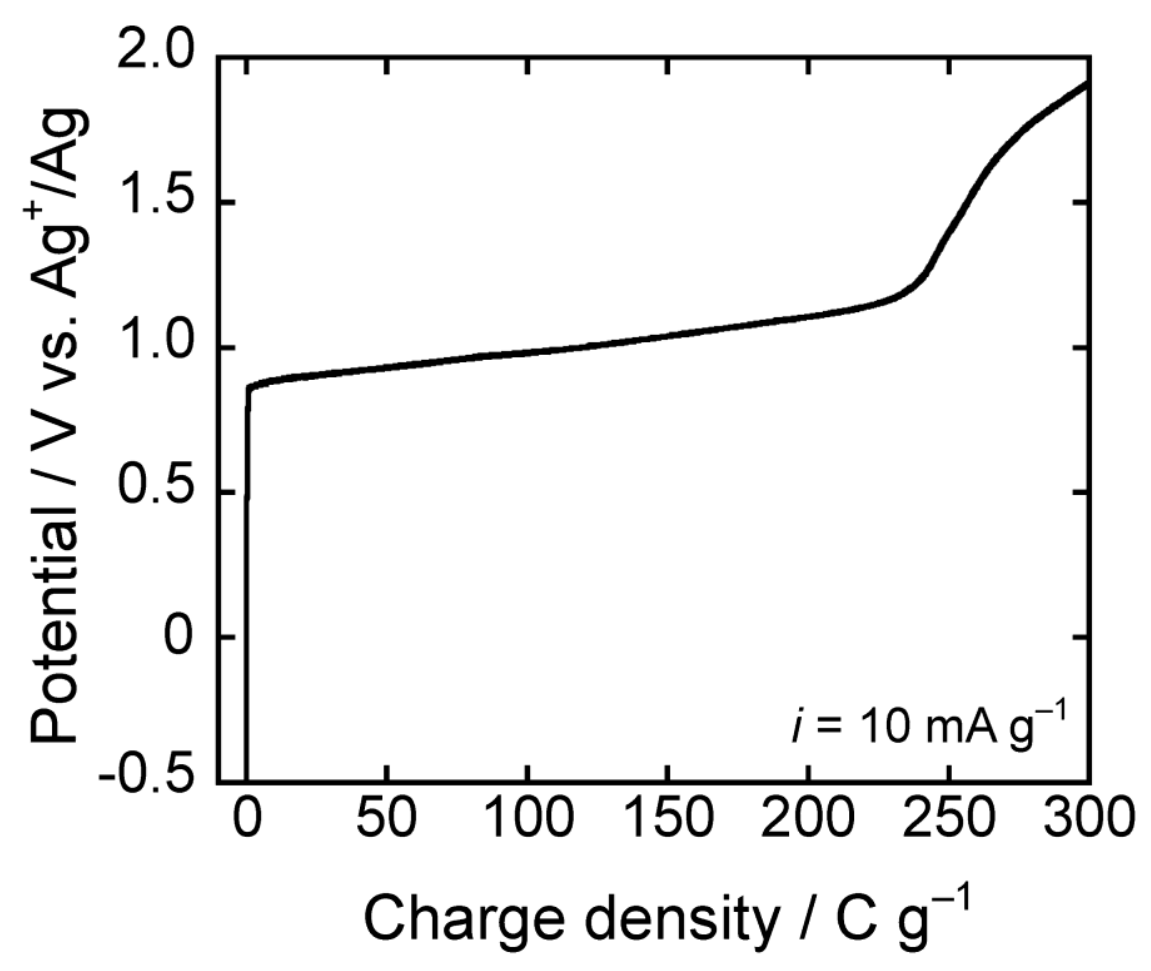

Figure 2 A galvanostatic charge profile of a graphite electrode in $1 \mathrm{M}$ [TEA][AlF 4$]$ / $\mathrm{CH}_{3} \mathrm{NO}_{2}$. 


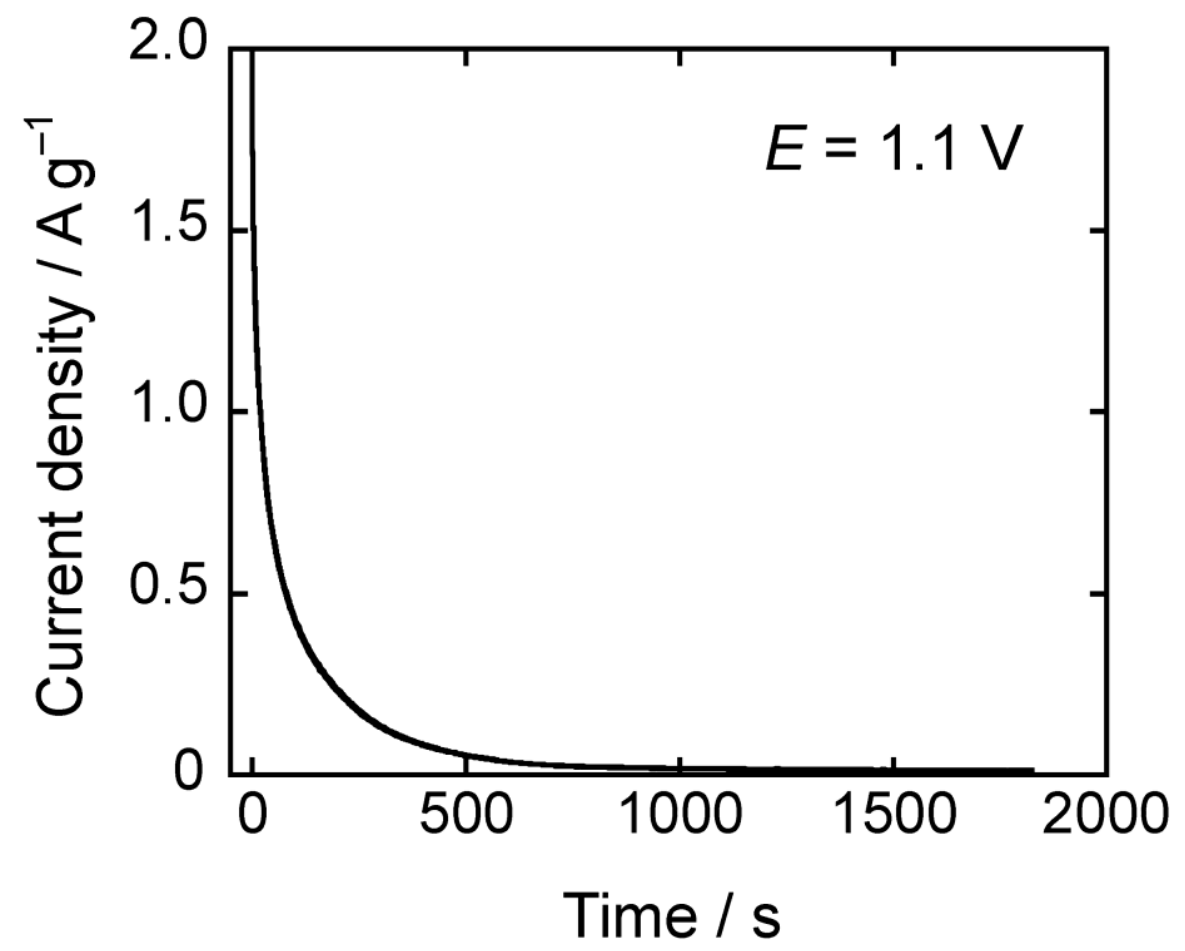

Figure 3 A chronoamperogram of a graphite electrode in $1 \mathrm{M}$ [TEA] $\left[\mathrm{AlF}_{4}\right] / \mathrm{CH}_{3} \mathrm{NO}_{2}$ during potentiostatic electrolysis at $1.1 \mathrm{~V}$ vs. $\mathrm{Ag}^{+} / \mathrm{Ag}$. 


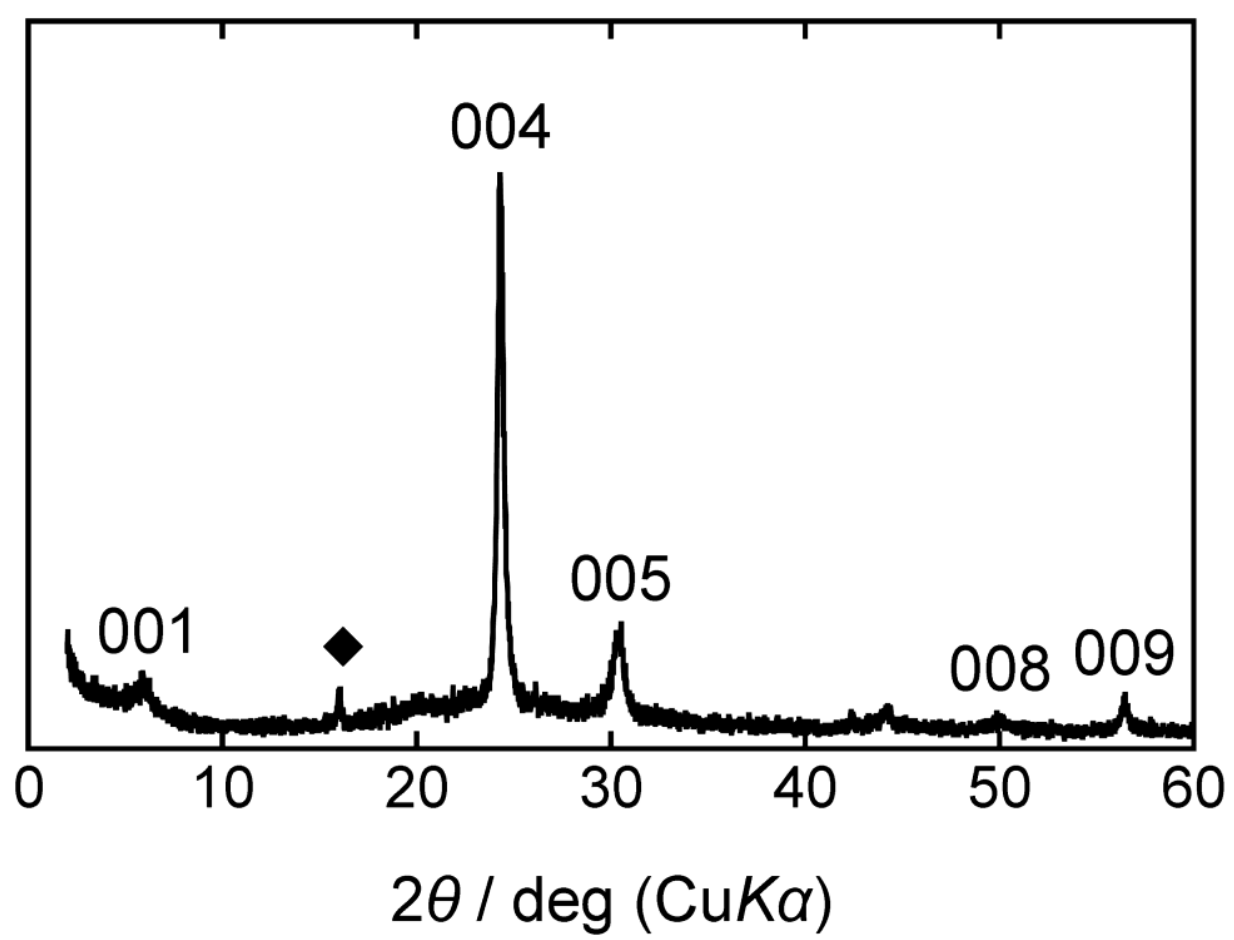

Figure 4 An X-ray diffraction profile of the graphite electrode obtained by potentiostatic electrolysis at $1.1 \mathrm{~V}$ vs. $\mathrm{Ag}^{+} / \mathrm{Ag}$ in $1 \mathrm{M}[\mathrm{TEA}]\left[\mathrm{AlF}_{4}\right] / \mathrm{CH}_{3} \mathrm{NO}_{2}$. The symbol denotes the strongest diffraction peak of [TEA] $\left[\mathrm{AlF}_{4}\right]$. 
(a)

(b)

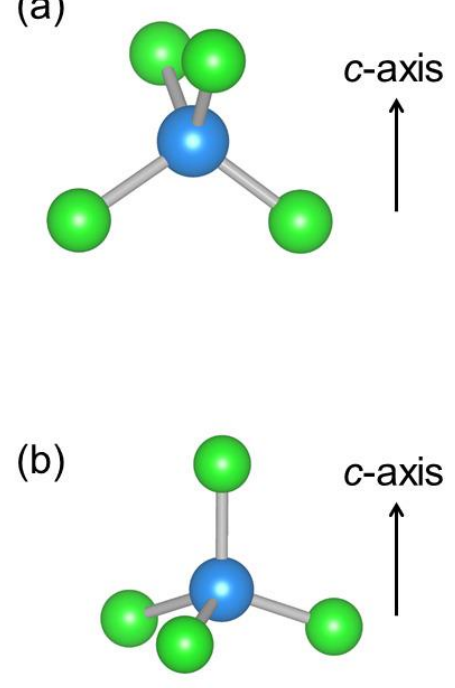

(c)

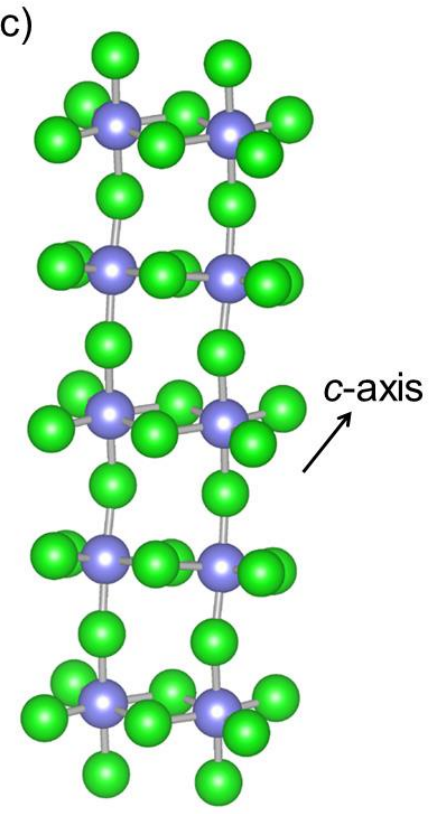

Figure 5 (Color online) A possible alignment of $\mathrm{AlF}_{4}{ }^{-}$in graphite layers; (a) the discrete $\mathrm{AlF}_{4}{ }^{-}$ with the $C_{2 v}$ axis perpendicular to the graphite layers, (b) the discrete $\mathrm{AlF}_{4}{ }^{-}$with the $C_{3 v}$ axis perpendicular to the graphite layers, and (c) the ladder-like $\left(\mathrm{Al}_{2} \mathrm{~F}_{8}{ }^{2-}\right)_{n}$ chain. The $c$-axis in the diagrams denotes the direction perpendicular to the graphite layers. 


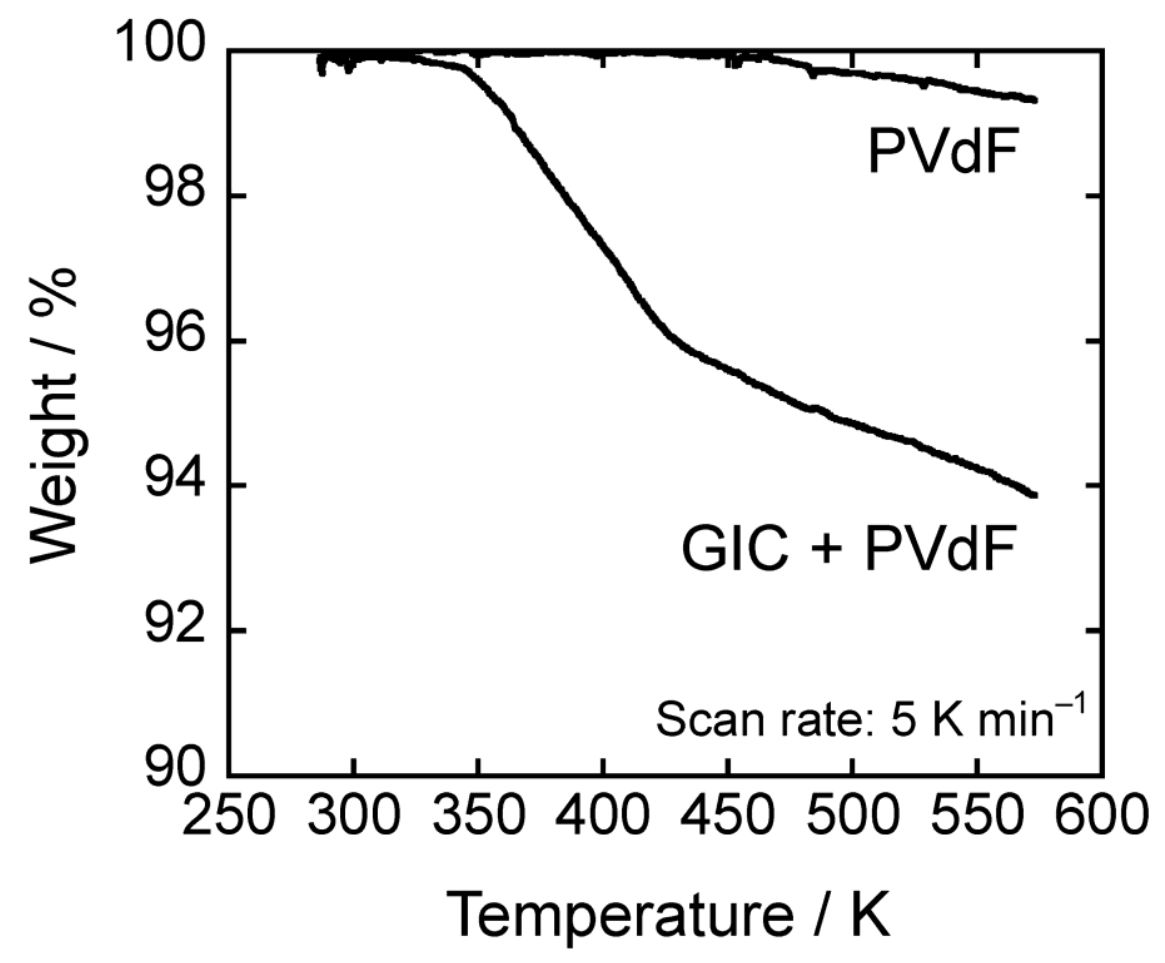

Figure 6 Thermogravimetric curves for PVdF and the stage-3 $\mathrm{AlF}_{4}-\mathrm{GIC}$. 


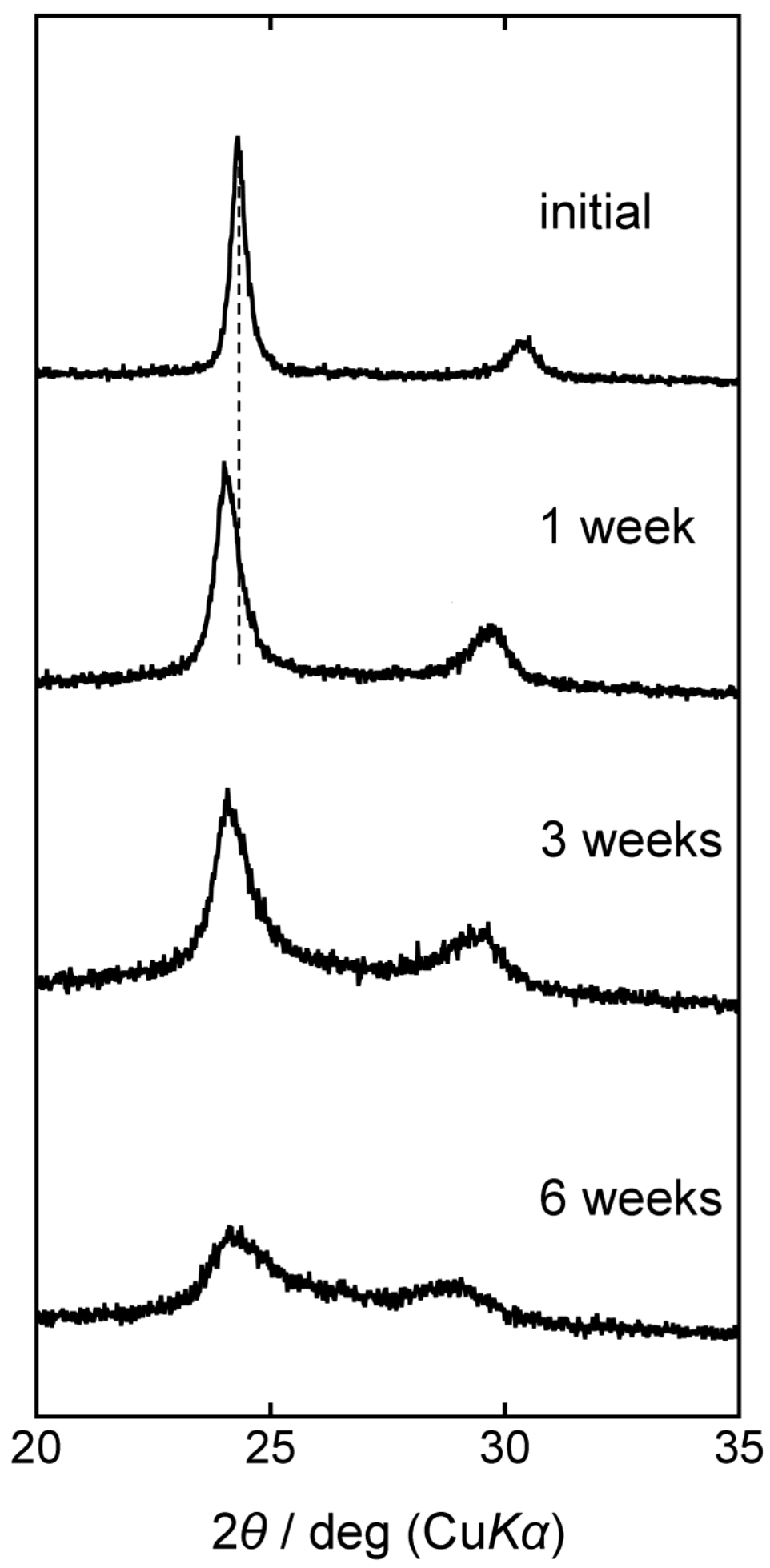

Figure $7 \mathrm{X}$-ray diffraction patterns of the stage- $3 \mathrm{AlF}_{4}-\mathrm{GIC}$ obtained by potentiostatic electrolysis at $1.1 \mathrm{~V}$ vs. $\mathrm{Ag}^{+} / \mathrm{Ag}$ in $1 \mathrm{M}[\mathrm{TEA}]\left[\mathrm{AlF}_{4}\right] / \mathrm{CH}_{3} \mathrm{NO}_{2}$ during exposure to the air at room temperature. 


\section{References}

$1 \quad$ M. S. Dresselhaus and G. Dresselhaus, Adv. Phys., 30, 139 (1981).

2 N. Bartlett and B. W. McQuillan, Graphite Chemistry, in Intercalation Chemistry, edited by e. S. M. Whittingham and A. J. Jacobsen, Academic Press, New York, 1982, p. 19.

3 H. Selig and L. B. Ebert, Adv. Inorg. Chem. Radiochem., 23, 281 (1980).

$4 \quad$ M. Noel and R. Santhanam, J. Power Sources, 72, 53 (1998).

5 D. D. L. Chung, J. Mater. Sci., 22, 4190 (1987).

6 A. Celzard, J. F. Mareche, and G. Furdin, Prog. Mater. Sci., 50, 93 (2005).

7 P. W. Ruch, M. Hahn, F. Rosciano, A. Holzapfel, H. Kaiser, W. Scheifele, B. Schmitt, P. Novak, R. Kotz, and A. Wokaun, Electrochim. Acta, 53, 1074 (2007).

8 Y. Yokoyama, N. Shimosaka, H. Matsumoto, M. Yoshio, and T. Ishiharaa, Electrochem. Solid-State Lett., 11, A72 (2008).

$9 \quad$ H. Selig and D. Brusilovsky, J. Fluorine Chem., 57, 15 (1992).

10 Z. Zhang and M. M. Lerner, J. Electrochem. Soc., 140, 742 (1993).

11 T. Ishihara, M. Koga, H. Matsumoto, and M. Yoshio, Electrochem. Solid-State Lett., 10, A74 (2007).

12 F. Okino, J. Fluorine Chem., 105, 239 (2000).

13 S. Karunanithy and F. Aubke, J. Fluorine Chem., 23, 541 (1983).

14 B. Ozmen-Monkul and M. M. Lerner, Carbon, 48, 3205 (2010).

15 W. Yan and M. M. Lerner, Carbon, 42, 2981 (2004).

16 N. Herron, R. L. Harlow, and D. L. Thorn, Inorg. Chem., 32, 2985 (1993).

17 N. Herron, D. L. Thorn, R. L. Harlow, and F. Davidson, J. Am. Chem. Soc., 115, 3028 (1993).

18 M. Ferbinteanu, H. W. Roesky, F. Cimpoesu, M. Atanasov, S. Kopke, and R. Herbst-Irmer, Inorg. Chem., 40, 4947 (2001). 
19 T. Nakajima, M. Kawaguchi, and N. Watanabe, Chem. Lett., 1045 (1981).

20 T. Nakajima, M. Kawaguchi, and N. Watanabe, Z. Naturforsch B, 36, 1419 (1981).

21 K. Matsumoto and R. Hagiwara, J. Fluorine Chem., 131, 805 (2011).

22 D. Peters and R. Miethchen, J. Fluorine Chem., 79, 161 (1996).

23 R. T. Carlin, H. C. Delong, J. Fuller, and P. C. Trulove, J. Electrochem. Soc., 141, L73 (1994).

24 A. Jobert, P. Touzain, and L. Bonnetain, Carbon, 19, 193 (1981).

25 G. R. Miller, H. A. Resing, M. J. Moran, L. Banks, F. L. Vogel, A. Pron, and D. Billaud, Synth. Met., 8, 77 (1983).

26 I. Y. Bagryanskaya and Y. V. Gatilov, J. Struct. Chem., 24, 150 (1983).

27 U. Bentrup, M. Feist, and E. Kemnitz, Prog. Solid State Chem., 27, 75 (1999).

28 K. Adil, M. Leblanc, V. Maisonneuve, and P. Lightfoot, Dalton Trans., 39, 5983 (2010).

29 U. Bentrup and W. Massa, Z. Anorg. Allg. Chem., 593, 207 (1991).

30 O. Knop, T. S. Cameron, S. P. Deraniyagala, and D. Adhikesavalu, Can J Chem, 63, 516 (1985).

31 X. Zhang, M. M. Lerner, H. Gotoh, and M. Kawaguchi, Carbon, 38, 1775 (2000).

32 N. Watanabe, H. Touhara, T. Nakajima, N. Bartlett, T. Mallouk, and H. Selig, Fluorine Intercalation Compounds of Graphite, in Inorganic Solid Fluorides, edited by P. Hagenmuller, Academic Press, New York 1985, p. 331.

33 N. Bartlett, F. Okino, T. E. Mallouk, R. Hagiwara, M. Lerner, G. L. Rosental, and K. Kourtakis, Oxidative Intercalation of Graphite by Fluoronanionic Species, in Advances in Chemistry Series No. 226, Electron Transfer in Biology and the solid State: Inorganic Compounds with Unusual Properties, edited by M. K. Johnson, R. B. King, D. M. Kurtz, C. Kutal Jr., M. L. Norton and R. A. Scott, American Chemcial Society, Washington, D. C., 1990., p. 391.

34 M. Lerner, R. Hagiwara, and N. Bartlett, J. Fluorine Chem., 57, 1 (1992). 
35 R. Hagiwara and N. Bartlett, Thermodynamic Aspects of the Intercalation of Graphite by Fluoroanions, in Fluorine-Carbon and Fluoride-Carbon Materials edited by T. Nakajima, Marcel Dekker, Inc. , New York, 1995, p. 67.

36 D. D. Wagman, W. H. Evans, V. B. Parker, R. H. Schumm, S. M. Bailey, I. Hallow, K. L. Churney, and R. L. Nuttall, Selected Values of Chemical Thermodynamic Properties, in National Bureau of Standards Technical Notes 270-3, 270-4, 270-5, 270-6, 270-7 and 270-8, Handbook of Chemistry and Physics, Vol. 70, CRC Press, Boca Raton, FL, 1989-1990.

37 J. L. Holm, Acta Chem. Scand., 27, 1410 (1973).

38 JANAF Thermodynamical Tables,1971. Clearinghouse for Federal Scientific and Technical Information, Springfield, Va., 1971. 